\title{
Prevalence of Parasitic Infections on Hematological Indices of Horses in the Gombe Royal Houses
}

\author{
Turaki U.A. ${ }^{\mathbf{1}}$, Zaifada A.U. ${ }^{\mathbf{2}}$, Alkali H.A ${ }^{\mathbf{1}}$, Galadima $\mathbf{U}^{\mathbf{3}}$. \\ ${ }^{1}$ Department of Animal science, Federal University Kashere \\ ${ }^{2}$ Veterinary Teaching hospital, University of Abuja \\ ${ }^{3}$ Department of Biological sciences, Federal University Kashere
}

Accepted January, 2019 and Published February, 2019

\begin{abstract}
The prevalence and effects of parasitic infections on hematological indices of horses in royal house of Gombe was studied. A total of 150 male horses were used for the study (January to March, 2017). Blood, feces and skin scrapings were collected from each horse and examined using various standard laboratory procedures. The coprological results showed that Ascaris accounted for 10\% (15), flatworms (fasciola) 4\% (6) and hookworms 4.6\% (7). The skin scrapings, Mange accounted for 4 (2.6\%), and ticks 8 (5.3\%) while hemoparasitological analysis showed that Babesia accounted for 5 (3.33\%). The blood indices showed that horses infected by parasites have significantly $(p<0.05)$ lower $R B C P C V, H B$, and platelets compared to non infected horses while the WBC values increased significantly $(p<0.05)$ due to immune-cellular response to the parasitic infection. The findings showed that parasitism is a problem in the stables examined and calls for proper stable hygiene, improved management practice, regular and strategic parasite monitoring and deworming programmes in order to achieve improved health and performance.
\end{abstract}

Keywords; Tick, endoparasite, Hemo-parasite, Horses, Hematological-indices, Prevalence.

*Corresponding Author:

E Mail: aishatu.zaifada@uniabuja.edu.ng

Tel: +2348036051134 


\section{INTRODUCTION}

Horses have been closely associated with man from ancient time [1]. The global equine population is estimated at 58 million [2] with Nigeria having about 240, 000 horses [3]. Indigenous horses in Nigeria are usedfor pleasure riding, polo games, ceremonies, crowd control, entertainment and research [4 \& 5]. These uses have encouraged horse owners to import exotic breeds to overcome the limitations of the available local breeds [6]. Also horses are associated with royalty and some special traditional festivals in the northern parts of Nigeria [7].

Parasite represents a significant threat to the health of animals [8]. The horse is susceptible to more than 60 parasites, and may harbour several species of worms at any time [ $9 \& 10]$. The effects of parasitic infection are more evident in young and undernourished horses. Parasitic disease have been reported to be the most prevalent disease of horses in Zaria (northern) Nigeria, accounting for $82.3 \%$ of cases presented to veterinary clinic over a period of 28 years [4]. While there was $23.5 \%$ prevalence of parasitic disease in horses in another report in some states (Bauchi, Kaduna and Plateau) in Northern Nigeria and this equine parasitic infection has been reported to be more prevalent $(28 \%)$ in local horses [11].

The prevalence of these infections and the associated changes in the clinical and haematological parameters of the animals have been extensively studied and reported from many countries [12 \& 13]. Hematological and sero-biochemical alterations are the indicators of severity of disease and are considered to be good tools for the diagnosis, prognosis for effective therapy [14]. However, despite several reports on the prevalence of parasitic diseases in horses in some parts of Nigeria $[1,4,11,15,16$ $\&$ 17] there is paucity of information on the parasitic infections and the associated changes in haematological parameters in local horses dominant in royal houses in Gombe, Northeastern Nigeria. Keeping in view the importance of blood profile of horses as an indicator of its good health and diseased condition, the present study is designed to investigate the effect of ecto and endoparasite infestation on the hematological parameters of naturally infected horses in the selected area.

\section{MATERIALSAND METHODS}

Horses: A total one hundred and fifty (150) adult male horses were randomly sampled over a period of 3months (January-March, 2017) in Gombe state, North-Eastern Nigeria. Horses stables belonging to royal houses (Emir and local chiefs) and individuals within Gombe Metropolis owners were used for this study, with an area of 18,768 square kilometers. The horses were usually grazed in open fields with occasional supplementation with crop residues during the few months of the rainy season but were permanently fed in the stabled with handcut grass and crop residues during the dry season.

Sample collection: The horses were routinely examined individually for both internal and external parasites and signs of their presence [18] following proper restraint. All external parasites seen were collected and preserved in labeled bottles containing $10 \%$ formalin. Skin scrapings were collected from mange-like lesions into clean petri-dishes. Blood samples (3milliliters) were collected from the jugular 
vein, using a hypodermic syringe fitted with an 18-gauge needle, into sample bottle with ethylene diamine tetra-acertic acid (EDTA) as anti-coagulant. About 10grams of feces were collected per rectum into an appropriately labeled air tight container and transported to the laboratory for analysis.

Analysis of samples: Skin scraping were placed in a test tube containing $10 \%$ potassium hydroxide solution and gradually brought to boil $\left(100^{\circ} \mathrm{C}\right)$ for 3 minutes in a water bath to remove excess tissue material. The test tube was allowed to cool and the content centrifuged for 2 minutes at $2,000 \mathrm{G}$. The supernatant solution as decanted and the sediment placed on a slide and examine microscopically [19]. Fecal samples were examined using the direct smear; sedimentation method and flotation technique employing saturated sodium chloride solution as the floating medium [19]. All the parasites recovered were identified using standard parasitological criteria [20]. Packed cell volume (PCV) was determined using the microhaematocrit method [21]. Wet Blood mounts and Giemsa stained thin and thick blood smears were routinely prepared and examined microscopically for parasites [21]. Determination of erythrocyte (RBC) count, white blood cells (WBC), platelets count and Haemoglobin (HB) was done as described by [20]. External parasites such as ticks were picked manually from the perineum below the tail into the petri-dish and taken to the laboratory for identification.

Statistical analysis: Data were summarized by descriptive statistic for mean, and standard deviation. Test of significance was done by oneway ANOVA, using Statistic ${ }^{\mathrm{R}}$ software and Pvalue less than or equall to 0.05 was considered significant.

\section{RESULT AND DISCUSSION}

Fourty-five (30\%) of the 150 horses examined had infection with hemoparasites, endoparasites and ectoparasite(Table 1). The prevalence of hemoparasites was 5 (3.33\%), endoparasites was $28(18.67 \%)$ and that of ectoparasite was $12(8.00 \%)$ while no parasite was found in $70 \%$ (105) of the horsesexamined. The non-detection of parasitism in $70 \%$ (105) horses examined could be due to the fact that they are stable animals managed intensively with zero grazing and [11] has also reported that stable management system appears to play a role in the prevalence of parasitism.

Table 1: prevalence of parasites infecting horses

\begin{tabular}{llll}
\hline PARASITES & & FREQUENCY & Total \\
\hline Hemoparasite & Babesia & $5(3.33 \%)$ & $5(3.33 \%)$ \\
Endoparasite & Ascaris & $15(10.00 \%)$ & $28(18.67 \%)$ \\
& Flatworms & $6(4.00 \%)$ & \\
& Hookworms & $7(4.67 \%)$ & \\
Ectoparasite & Mange & $4(2.67 \%)$ & $12(8.00 \%)$ \\
& Ticks & $8(5.33 \%)$ & \\
& TOTAL & $\mathbf{4 5 ( 3 0 \% )}$ & \\
& & & \\
\hline
\end{tabular}


The nature and extent of damage caused by parasite varies with the type of parasite. Despite the attention given to horse management in northern Nigeria compared to domestic livestocks, our finding shows that parasitismis a problem in the horse stables examined as previously reported by [11]. The parasites observed in all the horses examined were Babesia (B. Caballi and T. equi) in 5 horses $(3.33 \%)$, ascaris (trichostrongyles and strongyles) in 15 horses (10\%), flatworms (tapeworms) in 6 horses (4\%) and liverflukes (Fasciola) in 7 horses (4.67\%). The finding that endoparasites is most prevalent (18.67\%) in this study is consistent with previous report $[4,11$ \& 17]. This suggests that the eggs and larvae of some parasites were brought to the horses' stables in grasses since some of the horses are on zero grazing. Although, the owner reported the often deworm their horses, the pasture environment or hand cut grasses when contaminated could result in the animals becoming re-infected even after the regular treatment regime [17]. Skin mange was observed in 4 horses which could be due to poorly managed stable, low roofing and poorly ventilated stables predisposing horses to growth of the manage. 8 horses had various degree of ticks infestation and they are the ones in which Babesia spp were detected in their blood samples.

Table 2: Hematological indices of infected and uninfected horses with ectoparasite and / or endoparasite examined in this study

\begin{tabular}{lll}
\hline Hemathological Indices & Infected horses & Uninfected \\
\hline RBC $\left(10^{6}\right)^{\text {g }}$ & $* 6.21 \pm 0.46(5.92-6.75)$ & $8.20 \pm 0.7(6.9-9.12)$ \\
HGB $(\mathrm{g} / \mathrm{dl})$ & $* 10.65 \pm 0.37(10.7-11.00)$ & $13.36 \pm 0.82(12.0-14.3)$ \\
PCV $(\%)$ & $* 30.85 \pm 1.34(29.9-31.8)$ & $38.38 \pm 3.9(32.7-44.2)$ \\
PLT $\left(10^{3}\right)$ g & $* 60.33 \pm 19.65(38-75)$ & $131.16+17.26(108-158)$ \\
WBC $\left(10^{9} / \mathrm{L}\right)$ & $* 13.0 \pm 2.50(11-14)$ & $8.0 \pm 2.6(8-10)$
\end{tabular}

*value significant at $\mathrm{p}<0.05$ 
These haematological findings above (table 2) revealed differences between infested and healthy group of horses in all the blood parameters studied. The mean PCV, Hgb, RBC, WBC and Platelet count in uninfected horses were $38.38 \pm 3.9 \%, 13.36 \pm 0.82 \mathrm{~g} / \mathrm{d} 1$, $8.20 \pm 0.7 \times 10^{6} / \mu \mathrm{L}, 8.0 \pm 2.6 \times 10^{9} / \mathrm{L}$ and $131.16+17.26 \times 10^{3} / \mu$ respectively. These values were within normal range. This observation may be due to an efficient management programme including the availability of adequate veterinary attention and regular and effective grooming of the animals. Meanwhile, the mean PCV, Hgb, RBC, WBC and Platelet count in infected horses were $30.85 \pm 1.34 \%, 10.65 \pm 0.37 \mathrm{~g} / \mathrm{dl}$, $6.21 \pm 0.46 \times 10^{6} / \mu \mathrm{L}, 13.0 \pm 2.50 \times 10^{9} / \mathrm{L}$ and $60.33 \pm 19.65 \times 10^{3} / \mu$ respectively.

There was a significantly $(p<0.05)$ lower PCV concentration in the infected horses $(30.85 \pm 1.34 \%)$ compared to the healthy horses $(38.38 \pm 3.9 \%)$. This is could be due to the fact that blood sucking parasites (internal and external) detected in collected samples reduce the number of circulating red blood cells thereby affecting the both the packed cell volume and hemoglobin content of the blood. This finding is consistent with established reports that gastrointestinal helminths, haemoand ectoparasites cause anaemia and clinical disease in susceptible horses [4, $22 \& 23]$. Meanwhile, [17] reported that large and small strongyles are known to be voracious blood suckers which could result in anemia in infected horse.
There was significant reduction $(P<0.05)$ in the haemoglobin $(\mathrm{Hb})$ levels of infested horses $(10.65 \pm 0.37 \mathrm{~g} / \mathrm{dl})$ as compared to non-infested horses $(13.36 \pm 0.82 \mathrm{~g} / \mathrm{dl})$. It was also observed that the lower haemoglobin level in infested horses was accompanied by lowered blood cell (RBC).

A significant lower $(P<0.05)$ RBC was observed in infested horses $(6.21 \pm 0.46 \times 10 / \mu \mathrm{L})$ as compared to non-infested group of horses $(8.20 \pm 0.7 \times 10 / \mu \mathrm{L})$. The reduction in the RBC counts occurred due to blood sucking by the ticks and worms as well as due to destruction of RBC's by the protozoan parasites (Babesia) transmitted by ticks seen in this study. Lower $\mathrm{Hb}$ and $\mathrm{RBC}$ are due to anaemia because of blood sucking ability of parasites and haemorrhage [20]. The results in the present study support the findings of other researchers who have also reported lowered RBC along with lowered $\mathrm{Hb}$ in animal infected with endo and ecto parasite [22 \& 24]. It is reported that macrocytic hypochromic anemia appeared in babesiosis (caused by Babesia) [25] and this was encountered in this study. In the present study, total white blood cell (WBC) count of the naturally infested horses were found to be significantly higher $(P<0.05)$ when compared to non-infested horses. Significantly higher $(P<0.05)$ WBC which may be due to inflammation caused by tick bite which leads to migration of white blood cells as a response toward the tick bite [22] or it could be due to response of white blood cell to intestinal infestation and mange as observed in this study. 
The platelet count of infected horses examined in this study was observed to be significantly higher $(P<0.01)$ as compared to that in the nonparasitized horses. Other researchers have also diagnosed thrombocytopenia (lower platelets count) due to tick and worm infestation in their respective studies [26 \& 27].

\section{CONCLUSIONAND}

\section{RECOMMENDATION}

Despite regular de-worming ectoparasite control in horses and stables studied, the horses still harbor wide variety of gastrointestinal worm, tick and hemoparasite which could affect horse health and performance. Therefore, there is need for proper stable hygiene, improved management practice with regular and strategic parasite monitoring and deworming programmes in order to achieve improved health and performance.

\section{Acknowledgement}

We acknowledgement the technical support of Mal. Umar Galadima and Mr. Bala Andy of Biology laboratory Federal University Kashere and Dr. S. Yuguda Consultant Hematologist Fed. Teaching Hospital Gombe.

\section{REFERENCES}

1. Nwosu C. O. and Stephen, M. (2005). Parasites and Associated Changes in Packed Cell Volume of Horses (Equus Caballus) in the Semi-Arid Zone, Norther-Eastern Nigeria. Animal Research International, 2(2): 329-331
2. Food and Agricultural Organization (FOA), (2007). The AHC's report by economic impact of horse industry in the United States. Pp. 228 - 235.

3. Molento, M. B. and Cole. G. C. (2008). Antihelmintic resistant nematodes in Brazilian horses Vet Rec. 162(12):380385.

4. Useh, N. M., Oladele, S. B., Ibrahim, N. D. G., Nok, A. J. and Esievo, K. A. N. (2005). Prevalence of Equine Diseases in the Northern Guinea Savannah of Zaria. Nigeria Journal of Equine Science. 16 (1): 27-28.

5. Ehizibolo, D.O., Gusi, A.M., Ehizibolo, P.O., Mbuk, E.U. and Ocholi, R.A. (2011). Serologic prevalence of brucellosis in horse stables in two northern states of Nigeria. Journal of Equine Science. 22:17-19

6. Saror, D.I. (1976). Haematological values in Nigerian Part-Arab Stallions. Vet. Rec. 99: 397-398.

7. Bukar, M. M., Sadiq, M.A. and Geidam, Y.A. (2007). A survey of cutaneous neoplasms among horses used for cultural festivals in Borno state, Nigeria. Nigerian Veterinary. Journal. 28:27-33.

8. Ademola, I.O., Fagbemi, B.O., and Idowu, S.O. (2004). Evaluation of the anthelmintic activity of Khaya senegalensis extract against gastrointestinal nematodes of sheep: in-vtro and in-vivo studies. Vet. Parasitol. 122:151-164. 
9. Charles, L. S., and Clare, H.P. (2003). Internal parasite of horses, V453 http://www.ag.ndsu.nodak.edu. Accessed June 13,2011.

10. Wannas, H. Y., Dawood, K. A. and Gassem, G. A. (2012). Prevalence of Gastro-intestinal parasites of Horses and Donkeys in Al Diwaniyah Governorate. Al Qadisiya Journal of Veterinary Medical Science. 11(1): 147-155.

11. Ehizibolo, D. O., Kamani, J., Ehizibolo P. O., Egwu, K. O., Dogo, G. O. and Salami-Shinaba, J. O. (2012). Prevalence and Signifcance of Parasites of Horses in Some States of Northern Nigeria Journall of Equine Science, 23(1):1-4.

12. Reilly, G. A. C. (1993). Two fatal cases of diarrhoea in horses associated with larvae of the small strongyles. Veterinary Record, 132: 267 -268

13. Javed, K., Ijaz, M., Ali, M. M., Khan, I., Mehmood, K. and Ali, S. (2014). Prevalence and Hematology of Tick Borne Hemoparasitic Diseases in Equines in and Around Lahore. Pakistan J. Zool. 46(2):401-408, 2014.

14. Col, R. and Uslu, U. (2007). Changes in selected serum components in cattle naturally infected with Theileria annulata. Bulletin of the Veterinary Institute in Pulawy. 51:15-18.

15. Nwosu, C. O., Srivastava, G. C. and Abdullahi, A. N. J. (1990). Helminth parasites of equines in Borno State,
Nigeria. Tropical Animal Production Investigation, $1: 9-13$

16. Turaki, U.A., Kumsha, H.A., Biu, A.A. and Bokko, P.B. (2014). Prevalence of Piroplasmosis amongst local horses in Northeastern. Journal of Agriculture and Veterinary Science, 7(12):4-7

17. Umar, Y.A., Maikaje D. B., Garba U.M. and Alhassan M. A. F. (2013) Prevalence of Gastro-Intestinal Parasites in Horses Used for Cadets Training in Nigeria. Journal of Veterinary Advances 2013, 3(2): 43-48

18. Hassan, A. Z. and Hassan, F. B. (2003). An introduction to veterinary practice. Ahmadu Bello University Press, Zaria, Nigeria, 389pp

19. Maff. (1977). Manual of Veterinary Parasitological Laboratory Techniques. Technical Bulletin No. 18, Ministry of Agriculture, Fisheries and Food, London. $129 \mathrm{pp}$.

20. Soulsby, E. J. L. (1982). Helminths, arthropods and protozoa of domesticated animals. $7^{\text {th }}$ edition, Baillere Tindall, London. 766-809 pp 21. Schalm, O. W., Jain, N. C. and Carroll, E. J. (1975). Veterinary Haematology, 3rd edn., Lea and Febiger, Philadelphia. 807 pp.

22. Kaur, D., Jaiswal, K. and Mishra, S. (2017). Effect of tick infestation on haematological parameters of calves. Journal of Entomology and Zoology Studies. 5(4): 107-111 
23. Alawa, C.B.I., Adamu, A.M., Gefu, J.O., Ajanusi. O.J., Abdu, P.A., Chiezey, N.P. Alawa, J.N., and Bowman, D.D. (2003). In vitro screening of two Nigerian medicinal plants (Vernonia amygdalina and Annona senegalensis) 26. for anthelmintic activity. Vet. Parasitol. 113: 73-81.

24. Rajendran, C and Hafeez, M. D. (2003). Haemato-biochemical changes and efficacy of different acaricides in cross bred animals. Indian Journal of Animal Science. 73(5):481-483.

25. Ibrahim, A. K., EL-Behairy, A. M., Mahran, K. A. and Awad, W. (20019).
Clinical and laboratory diagnosis of piroplasmids in naturally infected cattle in Egypt. Journal of Egyptian Veterinary and Medical Association. 69(2):105-203.

26. Mahmood, A. (1994). Effect of theleriosis on various blood parameters and total serum protein in exotic and crossbred cattle in and around Lahore. M.Sc (Hons.) Thesis, Univ. of Agric. (CVS ), F a is a lab ad, 1994. 27. Haseeb, A. K. (2001). Studies on Babesia canis and ticks of dogs. M.Sc (Hons.) Thesis, Univ. of Agric. (CVS), Faisalabad,2001. 